\title{
DEPRESSION AS A RISK FACTOR FOR OSTEOPOROSIS
}

\author{
Giovanni Cizza ${ }^{1}$, Svetlana Primma ${ }^{1}$, and Gyorgy Csako $^{2}$ \\ ${ }^{1}$ Clinical Endocrine Section, Clinical Endocrinology Branch, NIDDK, NIH, DHHS \\ ${ }^{2}$ Department of Laboratory Medicine, Clinical Center, NIH, DHHS
}

\begin{abstract}
Osteoporosis is a major public health threat. Multiple studies have reported an association between depression and low bone mineral density, but a causal link between these two conditions is disputed. Here we review the endocrine and immune alterations secondary to depression that might affect bone mass. We also discuss the possible role of poor lifestyle in the etiology of osteoporosis in subjects with depression and the potential effect of antidepressants on bone loss. We propose that depression induces bone loss and osteoporotic fractures, primarily via specific immune and endocrine mechanisms, with poor lifestyle habits and use of specific antidepressants also potential contributory factors.
\end{abstract}

\section{Unrecognized link between depression and osteoporosis}

Osteoporosis is a public health threat. In 2005, more than 2 million fractures occurred in the United States, $70 \%$ of which occur in women, with a healthcare system financial strain of 17 billion dollars [1]. This burden is predicted to increase and by 2020, it is predicted that 14 million women and men will be affected by osteoporosis in the US with a projected $50 \%$ increase in fractures at a cost of 25 billion dollars per year [1].

Recognized risk factors for osteoporosis include menopause, Caucasian or Asian race, a thin frame, physical inactivity, smoking, alcohol use, inadequate calcium and vitamin D intake, corticosteroid use, and certain medical conditions. We suggest depression as another risk factor for osteoporosis. Major depressive disorder (MDD) is an important cause of disability in the US and one of the leading causes of disability worldwide [2]. Despite a large body of evidence, however, depression is not listed among the risk factors for osteoporosis [3]. We suggest a causal link between MDD and osteoporosis, analyze the clinical consequences of this relationship, and propose potential mechanisms.

\section{Relationship between depression, bone mass, and osteoporotic fractures}

Schweiger et al. reported a 15\% deficit in spine bone mass measured by computed tomography (CT) in patients with major depression, spurring a growing number of reports. Many of these relevant reports investigating a potential relationship between depression and osteoporosis were described in detail in our previous review article [4] and are listed in Table 1.

Please send all correspondence and reprint requests to: Giovanni Cizza, M.D., Ph.D. MH.Sc. Building 10, CRC, Rm. 6-3940 Bethesda, MD 20892-1613 cizzag@intra.niddk.nih.gov Phone \# (301) 496-8711 Fax \# (301) 480-2047.

DISCLOSURE STATEMENT No conflict of interest to disclose.

Publisher's Disclaimer: This is a PDF file of an unedited manuscript that has been accepted for publication. As a service to our customers we are providing this early version of the manuscript. The manuscript will undergo copyediting, typesetting, and review of the resulting proof before it is published in its final citable form. Please note that during the production process errors may be discovered which could affect the content, and all legal disclaimers that apply to the journal pertain. 
Determining whether decreased bone mass in subjects with depression translates into increased fracture risk is critical. Bone mineral density (BMD) is considered a reliable predictor for fractures, accounting for approximately $70 \%$ of the risk variability [5]. The remaining $30 \%$ might depend on factors such as biomechanical bone strength and anatomical properties not captured by conventional methods, such as dual-energy X-ray absorptiometry (DXA) measurements [6]. In a large study of patients with hip fractures, approximately half of the subjects were not osteoporotic at the hip [7], confirming that, in addition to BMD, other factors contribute to fracture risk. Because of the need for a large sample and long follow-up, few studies have examined osteoporotic fracture prevalence in subjects with depression.

In the Multiple Outcomes of Raloxifene Evaluation Trial, postmenopausal women with vertebral fractures reported more depressive symptoms than women without vertebral fractures [8], but it remained unclear whether depression was reactive to fractures or causative. In a prospective study of older Mexican-American women, higher levels of depression predicted self-reported fractures [9]. In a prospective, population-based study of women aged 50 or older conducted in Norway, women with the highest level of distress, defined as depression associated with life dissatisfaction, nervousness, loneliness, sleep disorders, and uneasy feelings, were at greater risk for hip fracture [10]. Likewise, in a large cohort of subjects aged 25 through 74 (NHANES I study) followed for 22 years, depression predicted hip fractures, a finding that remained significant after adjusting for age, gender, race, body mass index (BMI), smoking, alcohol, and physical activity [11]. Interestingly, no significant differences were found in the spine or femur BMD between depressed women and controls. Middle-aged women with depression had a $40 \%$ increase in risk for non-vertebral fractures compared to women without depression [12]. This association remained strong in women with depression after adjusting for increased falls propensity. In summary, a large body of evidence supports a causal link between MDD and osteoporosis and osteoporotic fractures, a possibility that should be investigated further at several bone sites of high fracture incidence, not only at the hip.

\section{Possible causative factors of bone mass deficit in subjects with depression}

The theoretical framework in Figure 1 depicts the synergistic action of endocrine and immune alterations underlying altered BMD and increased bone fragility in subjects with MDD.

\section{Hypothalamo-pituitary-adrenal (HPA) axis and the role of cortisol}

Hypercortisolemia is considered an important causative factor of bone deficit in depression. Depression causes a sustained and protracted activation of the stress system, activating the hypothalamic corticotropin-releasing hormone (CRH) neuron via circuits connecting the prefrontal cortex, the hippocampus, the amygdala, and the hypothalamus, thereby increasing cortisol. Of note, increases in plasma cortisol or urinary free cortisol (UFC) are usually much less pronounced in depression than in Cushing syndrome. However, cortisol has been measured only in a small number of studies focused on depression and osteoporosis. These studies documented either increased plasma cortisol $[13,14]$ or increased UFC [15] with no differences found in other studies [13,16-20]. Mild alterations of the HPA axis in depression become more apparent under stress, e.g. salivary cortisol following a public speech task was higher in 9 depressed postmenopausal women compared to 10 non-depressed postmenopausal women [21]. Depressed women also had significantly lower total lumbar and right femur BMD, demonstrating a negative relationship between post-stress salivary cortisol and BMD. In most of these studies, subjects with depression were pharmacologically treated. Therefore, cortisol values in these studies might be variable due to normalization of hypercortisolemia secondary to clinical improvement. Also, circadian variability and the fact that cortisol levels are sensitive to venipuncture (involved in testing BMD) could contribute to variability in findings. In summary, alterations of the HPA axis are established features in patients with depression, but 
they may or may not be evident depending on the severity of depression and the specific parameters of the HPA axis that are measured.

\section{Sympathetic system}

Whereas the importance of the HPA axis in the pathogenesis of bone loss secondary to depression has been recognized for a long time, Yirmiya et al. recently shifted focus to the role of the other efferent limb of the stress system, the catecholaminergic axis. Stress causes bone loss in rodents via increased activity of this axis [22]. A two week exposure of mice to various severe stressors resulted in bone loss that was preventable by antidepressants and mediated by increased activity of the catecholaminergic system, as it could be partially ameliorated by $\beta$ blockers [22].

The POWER Study did not detect differences in urine epinephrine, norepinephrine, and dopamine levels (as obtained from 24-h urine collection) between depressed women and controls [16]; however, it is possible that measurements of urinary catecholamines might not be sufficiently sensitive to detect changes in the sympathetic system secondary to mood alterations [23]. Very recently, the population-based First Israeli Health Interview Survey reported a strong association between generalized anxiety disorders (GAD) (independent of major depression) and osteoporosis [24]. Interestingly, the prevalence of fractures is lower in subjects on $\beta$-blockers [25], implicating that increased activity of the sympathetic-adrenal system might play a role in osteoporosis.

We advocate more clinical research in this area, especially in conditions such as post-traumatic stress disorder (PTSD), characterized by alterations of the sympathetic nervous system.

\section{Leptin}

Leptin causes bone loss in rodents by centrally inhibiting bone formation via activation of the sympathetic system [26]. Reports of serum leptin levels in depressed subjects are conflicting, with studies finding either no differences [13,27], lower levels in depressed men [28], elevated levels in depressed men and women [29], or elevated levels only in depressed women [30]. These studies might be conflicting because it is difficult to disentangle in observational investigations the direct effect of mechanical stimulation (increased body weight) on the osteoblast vs. the effect of a fat product, i.e. leptin on the neuroendocrine bone axis. It is also possible that leptin's involvement in bone loss is influenced by mechanical stimulation. For example, load exercise directly stimulates the osteoblast, so one can assume that heavier people with presumably more fat mass tend to have stronger bones. A negative effect of leptin on bone mass would still be compatible with higher body weight being stimulatory to bone, if one considers that leptin has a wide normal range, and two individuals with the same amount of fat mass might have different leptin levels [31]. From these studies then, it is apparent that further research on the correlation between the leptin axis and depression is needed.

\section{Immune factors: the role of cytokines}

Depression is associated with immune dysregulation characterized by increased cytokine activity, specifically that of interleukin-1, interleukin- 6 , and tumor necrosis factor- $\alpha$ (TNF- $\alpha$ ) [32]. Cytokines are potent stimulators of the HPA axis and might contribute to hypercortisolism in depression. However, only a few studies have tested this question.

We found a profound dysregulation of plasma cytokines, measured hourly for $24 \mathrm{~h}$ (from $8 \mathrm{am}$ until 8 am the next day). Levels of pro-inflammatory cytokines IL-1 $\beta$, IL-2, IL-6 and TNF $\alpha$ were significantly increased in premenopausal women in remission from depressive symptoms compared to age/BMI/ethnicity-matched healthy controls, whereas anti-inflammatory IL-10 values were lower, and the anti-inflammatory IL-13 levels were similar between the two groups 
[16]. Increased levels of TNF- $\alpha$ and IL-6 [13], with no differences in TNF- $\alpha$ receptors, were also reported [27]. To study immune alterations non-invasively, we developed a method to quantify cytokines in sweat. Cytokine levels in sweat correlated closely with plasma levels, making this non-invasive approach potentially applicable to large-scale studies [33]. Increased levels of oxidative stress might represent another potential pathway to both depression and osteoporosis [34]. More research is needed in this promising area.

\section{Vitamin D and parathyroid hormone (PTH)}

Several studies reported an association between vitamin D and PTH in depression [13,14, $16-20,27,35]$. We found that women with depression had slightly higher PTH, lower $25-\mathrm{OH}$ vitamin $\mathrm{D}$ and ionized calcium levels when compared to controls [16]. Interestingly, low vitamin D levels might play a role in seasonal affective disorder (SAD), a clinical variant of depression that worsens in the Northern hemisphere during winter, because SAD improves with vitamin D supplementation, sun exposure and light therapy. The presence of vitamin D receptors in several human brain areas involved in neuroendocrine and autonomic functions such as the hypothalamus, the nucleus basalis of Meynert and the substantia nigra [36], might provide additional evidence for a direct role of vitamin $\mathrm{D}$ in modulating mood and behavior in depression.

\section{Gender effects}

Little attention has been paid to the role of estrogens in osteoporosis-related depression. No major differences were evident in the age at menarche [14,16,18,19,37], number of pregnancies $[14,16,18]$, oral estrogen use [38,39], or irregular menses [17] between subjects with depression vs. controls.

Another unanswered research question is whether there is a different susceptibility in women $v s$. men to fractures associated with depression. Bone mass is generally lower in men with depression compared to non-depressed men, especially at the total femur [30,40-42]. Men tend to have fractures at higher BMD values than women [43]. In a longitudinal cohort study conducted in Norway, both pre- and post-menopausal women with mental distress (defined as depression insomnia and coping problems) had increased fracture risk, but this association was not found in men [44]. Use of antidepressants such as fluoxetine has been associated with low testosterone levels in older men and increased prolactin in both genders. Conversely, testosterone supplementation in men seems to improve some of the symptoms of depression.

There is a strong need for rigorous studies on the effects of antidepressants on testosterone levels and the potential repercussions on bone mass. During reproductive years, women commonly experience periodic disruptions of the ovarian cycle that translate into transient hypoestrogenemia. These episodes are often triggered by increased stress and anxiety. More research is needed to examine the contribution of alterations of the menstrual cycle on depression-induced osteoporosis in women. Physicians should encourage women to maintain a monthly record of their menstrual cycle. A potential interaction between sex hormones and skeletal sites also requires further investigation.

\section{Life style factors and osteoporosis}

The association between depression and osteoporosis might be mediated or perpetuated by an unhealthy lifestyle. This question has generally been addressed in a retrospective fashion and often in a self-reported form. Such studies report no differences in dietary calcium intake [16,37-40] or calcium supplementation [12,35] in subjects with depression compared with controls. Smoking has been correlated with bone loss [3], but only a few studies reported that depressed subjects contained a higher proportion of smokers $[11,12,40]$ and more often, no differences were found between groups [8,16-18,38,39,41,45-47]. Weight-bearing physical 
activity helps maintain bone mass and in general, subjects with depression were less active than controls $[12,38,41,42,46,48,49]$, but some studies observed no differences in physical activity $[11,16,35,40]$. Low BMI is a well-known risk factor for osteoporosis and fractures [50]. In lean elderly women with depressive symptoms, life-long exercise was protective against falls and fractures [48]. Alcohol intake is also an established risk factor for osteoporosis [3] and yet was found to be either similar in subjects with depression and controls $[16,40-42$, $51,52]$ or significantly lower in subjects with depression $[11,12,46]$. Therefore this factor is unlikely to play a role in determining low bone mass in subjects with depression. Sleep disturbances and sleep deprivation, which are often observed in MDD, are known to increase cortisol levels and promote pro-inflammatory cytokines [53], suggesting an additional link between depression and osteoporosis. Based on the limited evidence available then, we suggest that lifestyle factors play a relatively small role in inducing bone loss in subjects with depression.

\section{Effect of antidepressants on bone mass and osteoporotic fractures}

Low bone mass in medicated psychiatric patients has been reported since the 1990's [4]. In a large cohort, elderly women on selective serotonin reuptake inhibitors (SSRIs) experienced greater bone loss at the hip, a class-specific effect because this was not observed in patients treated with tricyclic antidepressants (TCAs) [39]. Serotonin transporter receptors have been identified on osteoblasts [54], making a direct effect on bone mass biologically plausible. Use of antidepressants, however, was not associated with lower bone mass in two small studies $[16,18]$; on the other hand, another study reporting even greater bone mass in a similar sample taking SSRIs [17]. Because of the limited statistical power in the smaller studies, those findings should be taken with caution.

Use of SSRIs and TCAs might induce fractures by increasing the risk of falls, especially in the elderly, possibly through cardiac arrhythmias or postural hypotension [55]. Two large studies in elderly subjects reported that subjects on SSRIs, secondary amine TCAs, and tertiary amine TCAs were at increased risk of hip fractures [56,57]. Use of SSRIs was associated with a 2.25 fold increase in fracture risk in a large cohort study conducted in Rotterdam [58]. In fact, this study identified a clear relationship between treatment duration and increased risk, detectable as early as 6 weeks after exposure. Antidepressant use was associated with more fractures at the spine and other sites, even in the absence of changes in BMD in 80,000 women aged 50 to 79 years, as reported by the Women's Health Initiative Observational Study [59].

As a large, case-control Danish study has revealed [60], fracture risk might differ among antidepressants. Most SSRIs were associated with a dose-dependent increase in fracture risk. TCAs with sedating effects such as amitriptyline and clomipramine were associated with fractures, whereas imipramine and clomipramine were not. Other antidepressants such as mianserin and mirtazapine carried no increased risk of fractures in this population.

\section{Depression, other co-morbidity psychiatric conditions, and osteoporosis}

MDD is often observed in association with anxiety and other mood disorders, but it is unclear whether psychiatric co-morbidity aggravates bone loss. Anxiety was associated with lower hip BMD in adolescent girls [45]. Also, BMD at the lumbar spine was lower in women with depression and borderline personality disorder compared to women with depression only [13]. Girls suffering from anorexia nervosa and depression also have lower BMD than girls with anorexia nervosa only [37]. Men, but not women, with depression and dysthimia, a chronic form of a depression disorder that is not as severe as MDD, had lower BMD at the level of the hip compared to men with depression only [40]. 


\section{Conclusions}

MDD is a risk factor for low BMD and fractures. This has been shown in middle-aged women, elderly subjects of both genders, White, African-Americans and Mexican-Americans, and for both vertebral and non-vertebral sites. A variety of mechanisms have been proposed to explain this association, but lifestyle factors and the use of a particular class of anti-depressants appear to play contributory roles. Irrespective of the specific cause(s), subjects with depression should be considered for screening for osteoporosis and, vice versa, subjects with decreased BMD should be considered for screening for depression. Adequately powered, well-adjusted, longitudinal, controlled studies of bone turnover also are warranted in subjects with depression. A summary of outstanding research questions is presented in Box 1.

\section{Box 1}

\section{OUTSTANDING RESEARCH QUESTIONS}

The overarching research goal is to further characterize the pathogenesis of osteoporosis in subjects with depression in the general context of the medical consequences of depression. Listed below are some of the most important questions that should be prospectively tested:

- The rate of developing bone deficit in depression should be established.

- Is peak bone mass ever fully achieved in subjects with depression?

- Are there critical life periods in which the skeleton is more susceptible to bone loss?

- The perimenopausal period, with its declining estrogen levels and concomitant mood changes, is a primary target for further studies.

- Despite requiring a long follow-up, the incidence of fractures in women with depression should be prospectively evaluated.

- The reversibility of bone loss, secondary to therapeutic interventions or spontaneous clinical resolution, should be explored.

- Further clinical evidence is needed to conclusively establish the potential side effects of SSRIs on bone mass in subjects with depression.

- Studies are needed to determine whether the association between depression and BMD is entirely mediated by the endocrine and immune alterations described here, and whether this association is more likely to be evident during active disease (state), or whether it is also associated with the condition of depression per se (trait) via some, as yet unclear, genetic mechanisms.

- Studies are needed to determine how genetic background might modulate the association between depression and fracture risk.

- More research also is warranted in men and women with anxiety disorders, especially PTSDs, in men suffering from depression, and in girls with depression and anxiety.

- The relationship between sleep disturbances and bone loss as well as fractures secondary to falls in sleep-deprived subjects with mood disorders, should be studied.

- Given the current obesity epidemic and the increasing use of bariatric surgery, the interaction between depression, weight loss, and bone loss should be studied in post-obese subjects with mood disorders. 


\section{ACKNOWLEDGMENTS}

This research was supported by the Intramural Research Programs of the National Institute of Diabetes, Digestive and Kidney Diseases and the Clinical Center, NIH.

\section{REFERENCES}

1. Burge R, et al. Incidence and economic burden of osteoporosis-related fractures in the United States, 2005-2025. J Bone Miner Res 2007;22:465-475. [PubMed: 17144789]

2. Ustun TB, et al. Global burden of depressive disorders in the year 2000. Br J Psychiatry 2004; 184:386392. [PubMed: 15123501]

3. Management of osteoporosis in postmenopausal women: 2006 position statement of The North American Menopause Society. Menopause 2006;13:340-367. 368-349. [PubMed: 16735931]quiz

4. Cizza G, et al. Depression: a major, unrecognized risk factor for osteoporosis? Trends Endocrinol Metab 2001;12:198-203. [PubMed: 11397644]

5. Kanis JA. Diagnosis of osteoporosis and assessment of fracture risk. Lancet 2002;359:1929-1936. [PubMed: 12057569]

6. Syed Z, Khan A. Bone densitometry: applications and limitations. J Obstet Gynaecol Can 2002;24:476484. [PubMed: 12196854]

7. Lyles KW, et al. Zoledronic Acid in Reducing Clinical Fracture and Mortality after Hip Fracture. N Engl J Med 2007;357nihpa40967

8. Silverman SL, et al. Prevalence of depressive symptoms in postmenopausal women with low bone mineral density and/or prevalent vertebral fracture: results from the Multiple Outcomes of Raloxifene Evaluation (MORE) study. J Rheumatol 2007;34:140-144. [PubMed: 17216681]

9. Tolea MI, et al. Depressive symptoms as a risk factor for osteoporosis and fractures in older Mexican American women. Osteoporos Int 2007;18:315-322. [PubMed: 17053870]

10. Forsen L, et al. Mental distress and risk of hip fracture. Do broken hearts lead to broken bones? J Epidemiol Community Health 1999;53:343-347. [PubMed: 10396480]

11. Mussolino ME. Depression and hip fracture risk: the NHANES I epidemiologic follow-up study. Public Health Rep 2005;120:71-75. [PubMed: 15736334]

12. Whooley MA, et al. Depression, falls, and risk of fracture in older women. Study of Osteoporotic Fractures Research Group. Arch Intern Med 1999;159:484-490. [PubMed: 10074957]

13. Kahl KG, et al. Bone mineral density, bone turnover, and osteoprotegerin in depressed women with and without borderline personality disorder. Psychosom Med 2006;68:669-674. [PubMed: 17012519]

14. Altindag $\mathrm{O}$, et al. Relation of cortisol levels and bone mineral density among premenopausal women with major depression. Int J Clin Pract 2007;61:416-420. [PubMed: 17313608]

15. Amsterdam JD, Hooper MB. Bone density measurement in major depression. Prog Neuropsychopharmacol Biol Psychiatry 1998;22:267-277. [PubMed: 9608600]

16. Eskandari F, et al. Low bone mass in premenopausal women with depression. Arch Intern Med 2007;167:2329-2336. [PubMed: 18039992]

17. Kavuncu V, et al. Bone metabolism and bone mineral density in premenopausal women with mild depression. Yonsei Med J 2002;43:101-108. [PubMed: 11854939]

18. Petronijevic M, et al. Low bone mineral density and high bone metabolism turnover in premenopausal women with unipolar depression. Bone 2008;42:582-590. [PubMed: 18226593]

19. Yazici AE, et al. Bone mineral density in premenopausal women with major depression. Joint Bone Spine 2005;72:540-543. [PubMed: 16046174]

20. Yazici KM, et al. Bone mineral density in premenopausal women with major depressive disorder. Psychiatry Res 2003;117:271-275. [PubMed: 12686369]

21. Furlan PM, et al. The role of stress-induced cortisol in the relationship between depression and decreased bone mineral density. Biol Psychiatry 2005;57:911-917. [PubMed: 15820712]

22. Yirmiya R, et al. Depression induces bone loss through stimulation of the sympathetic nervous system. Proc Natl Acad Sci U S A 2006;103:16876-16881. [PubMed: 17075068] 
23. Yu BH, et al. Mood states, sympathetic activity, and in vivo beta-adrenergic receptor function in a normal population. Depress Anxiety 2008;25:559-564. [PubMed: 17583588]

24. Muhsen K, et al. Correlates of generalized anxiety disorder: independent of co-morbidity with depression: Findings from the first Israeli National Health Interview Survey (2003-2004). Soc Psychiatry Psychiatr Epidemiol 2008;43:898-904. [PubMed: 18642124]

25. Schlienger RG, et al. Use of beta-blockers and risk of fractures. Jama 2004;292:1326-1332. [PubMed: 15367554]

26. Takeda S. Central control of bone remodelling. J Neuroendocrinol 2008;20:802-807. [PubMed: 18601702]

27. Kahl KG, et al. Decreased osteoprotegerin and increased bone turnover in young female patients with major depressive disorder and a lifetime history of anorexia nervosa. Osteoporos Int 2005;16:424429. [PubMed: 15300363]

28. Kraus T, et al. Low leptin levels but normal body mass indices in patients with depression or schizophrenia. Neuroendocrinology 2001;73:243-247. [PubMed: 11340338]

29. Antonijevic IA, et al. Elevated nocturnal profiles of serum leptin in patients with depression. J Psychiatr Res 1998;32:403-410. [PubMed: 9844957]

30. Esel E, et al. Effects of antidepressant treatment and of gender on serum leptin levels in patients with major depression. Prog Neuropsychopharmacol Biol Psychiatry 2005;29:565-570. [PubMed: 15866359]

31. Isidori AM, et al. Leptin and aging: correlation with endocrine changes in male and female healthy adult populations of different body weights. J Clin Endocrinol Metab 2000;85:1954-1962. [PubMed: 10843181]

32. Marques-Deak A, et al. Brain-immune interactions and disease susceptibility. Mol Psychiatry 2005;10:239-250. [PubMed: 15685252]

33. Cizza G, et al. Elevated neuroimmune biomarkers in sweat patches and plasma of premenopausal women with major depressive disorder in remission: the POWER study. Biol Psychiatry 2008;64:907-911. [PubMed: 18657799]

34. Pasco, JA., et al. Oxidative stress may be a common mechanism linking major depression and osteoporosis. 2008. p. 112-116.

35. Michelson D, et al. Bone mineral density in women with depression. N Engl J Med 1996;335:11761181. [PubMed: 8815939]

36. Eyles DW, et al. Distribution of the vitamin D receptor and 1 alpha-hydroxylase in human brain. $\mathrm{J}$ Chem Neuroanat 2005;29:21-30. [PubMed: 15589699]

37. Konstantynowicz J, et al. Depression in anorexia nervosa: a risk factor for osteoporosis. J Clin Endocrinol Metab 2005;90:5382-5385. [PubMed: 15941868]

38. Diem SJ, et al. Depressive symptoms and rates of bone loss at the hip in older women. J Am Geriatr Soc 2007;55:824-831. [PubMed: 17537081]

39. Diem SJ, et al. Use of antidepressants and rates of hip bone loss in older women: the study of osteoporotic fractures. Arch Intern Med 2007;167:1240-1245. [PubMed: 17592096]

40. Mussolino ME, et al. Depression and bone mineral density in young adults: results from NHANES III. Psychosom Med 2004;66:533-537. [PubMed: 15272099]

41. Whooley MA, et al. Depressive symptoms and bone mineral density in older men. J Geriatr Psychiatry Neurol 2004;17:88-92. [PubMed: 15157349]

42. Wong SY, et al. Depression and bone mineral density: is there a relationship in elderly Asian men? Results from Mr. Os (Hong Kong). Osteoporos Int 2005;16:610-615. [PubMed: 15448988]

43. Haney EM, Bliziotes MM. Male osteoporosis: new insights in an understudied disease. Curr Opin Rheumatol 2008;20:423-428. [PubMed: 18525355]

44. Sogaard AJ, et al. Long-term mental distress, bone mineral density and non-vertebral fractures. The Tromso Study. Osteoporos Int 2005;16:887-897. [PubMed: 15618997]

45. Dorn LD, et al. Association of depressive symptoms and anxiety with bone mass and density in eversmoking and never-smoking adolescent girls. Arch Pediatr Adolesc Med 2008;162:1181-1188.

[PubMed: 19047547] 
46. Robbins J, et al. The association of bone mineral density and depression in an older population. J Am Geriatr Soc 2001;49:732-736. [PubMed: 11454111]

47. Schweiger U, et al. Lumbar bone mineral density in patients with major depression: evidence of increased bone loss at follow-up. Am J Psychiatry 2000;157:118-120. [PubMed: 10618024]

48. Korpelainen R, et al. Lifelong risk factors for osteoporosis and fractures in elderly women with low body mass index--a population-based study. Bone 2006;39:385-391. [PubMed: 16530030]

49. Milliken LA, et al. Depressive symptoms and changes in body weight exert independent and sitespecific effects on bone in postmenopausal women exercising for 1 year. J Gerontol A Biol Sci Med Sci 2006;61:488-494. [PubMed: 16720746]

50. Ravn P, et al. Low body mass index is an important risk factor for low bone mass and increased bone loss in early postmenopausal women. Early Postmenopausal Intervention Cohort (EPIC) study group. J Bone Miner Res 1999;14:1622-1627. [PubMed: 10469292]

51. Jacka FN, et al. Depression and bone mineral density in a community sample of perimenopausal women: Geelong Osteoporosis Study. Menopause 2005;12:88-91. [PubMed: 15668605]

52. Niti M, et al. Depression and chronic medical illnesses in Asian older adults: the role of subjective health and functional status. Int J Geriatr Psychiatry 2007;22:1087-1094. [PubMed: 17407107]

53. Evans DL, et al. Mood disorders in the medically ill: scientific review and recommendations. Biol Psychiatry 2005;58:175-189. [PubMed: 16084838]

54. Bliziotes MM, et al. Neurotransmitter action in osteoblasts: expression of a functional system for serotonin receptor activation and reuptake. Bone 2001;29:477-486. [PubMed: 11704501]

55. Pacher $\mathrm{P}$, et al. Serotonin reuptake inhibitors fluoxetine and citalopram relax intestinal smooth muscle. Can J Physiol Pharmacol 2001;79:580-584. [PubMed: 11478591]

56. Hubbard R, et al. Exposure to tricyclic and selective serotonin reuptake inhibitor antidepressants and the risk of hip fracture. Am J Epidemiol 2003;158:77-84. [PubMed: 12835289]

57. Liu G, Peacock M. Age-related changes in serum undercarboxylated osteocalcin and its relationships with bone density, bone quality, and hip fracture. Calcif Tissue Int 1998;62:286-289. [PubMed: 9504950]

58. Ziere G, et al. Selective serotonin reuptake inhibiting antidepressants are associated with an increased risk of nonvertebral fractures. J Clin Psychopharmacol 2008;28:411-417. [PubMed: 18626268]

59. Spangler L, et al. Depressive symptoms, bone loss, and fractures in postmenopausal women. J Gen Intern Med 2008;23:567-574. [PubMed: 18286345]

60. Vestergaard P, et al. Selective serotonin reuptake inhibitors and other antidepressants and risk of fracture. Calcif Tissue Int 2008;82:92-101. [PubMed: 18219438] 


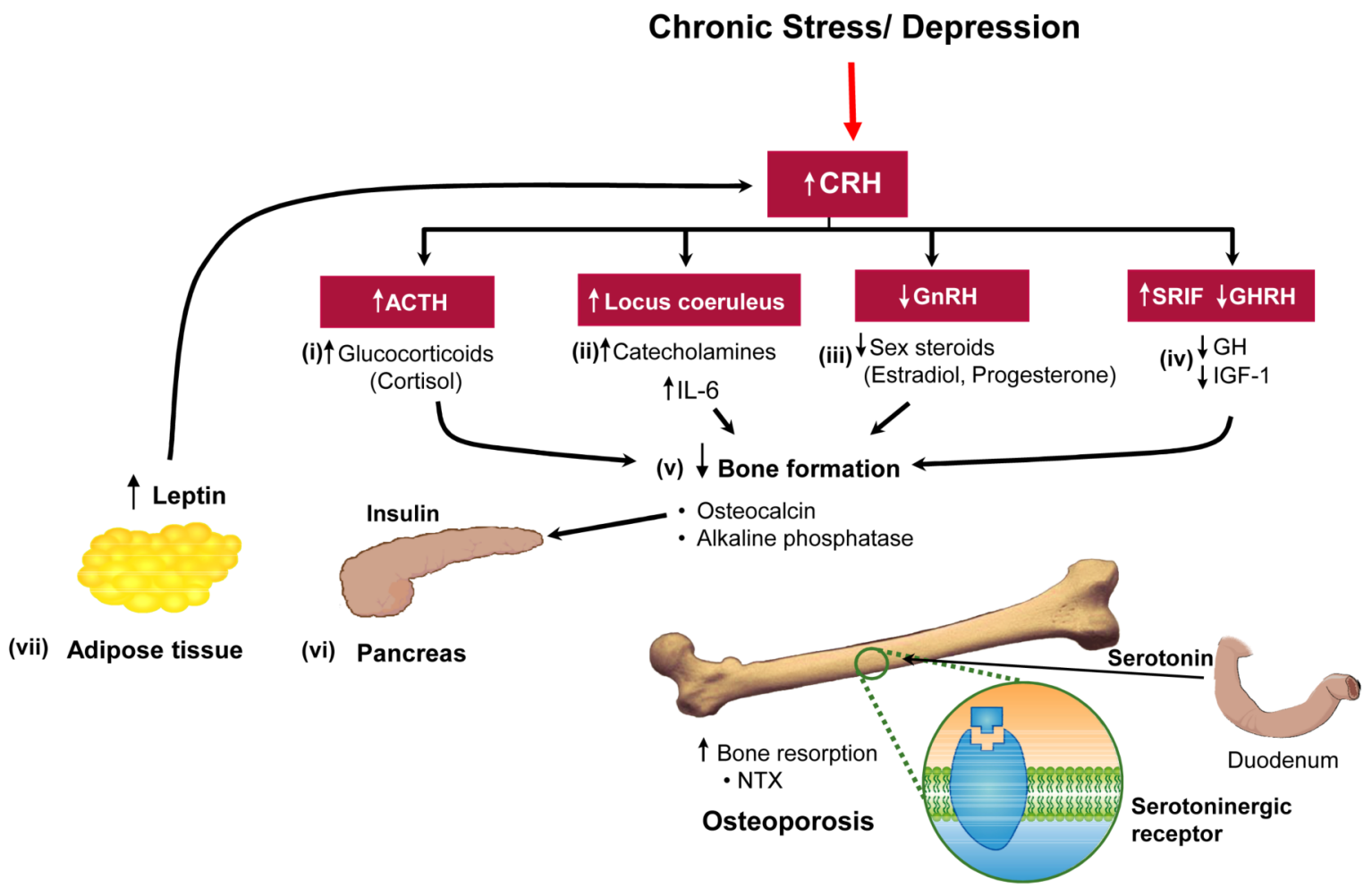

Figure 1.

Potential mechanisms of bone loss in depression. The model implicating hypercortisolemia (i) as a major cause of osteoporosis is derived from the well-known effect of increased cortisol in subjects with Cushing syndrome. The other main effector branch of the stress system, the sympathetic system (ii), modulates the production of pro-inflammatory cytokines, including interleukin (IL)-6, a potent bone resorption agent. As evolutionarily appropriate in a situation of chronic stress such as depression, the processes for reproduction and growth become inhibited, which results in decreased levels of estrogens (iii) and growth hormone (GH)/insulinlike growth factor (IGF)-1 (iv). Taken together, the combination of increased cortisol, IL-6, decreased sex steroids and GH lead to reduced bone mass, as the net result of decreased bone formation and increased bone resorption according to the markers of bone turnover.

Physiological amounts of osteocalcin regulate (v) insulin expression (vi) in the pancreas and adiponectin in (vii) adipose tissue. The complex endocrine and immune imbalances depicted in this figure predispose subjects with depression to other serious medical consequences such as central obesity, altered insulin sensitivity, subclinical inflammation, and increased cardiovascular morbidity and mortality. CRH, corticotropin-releasing hormone; ACTH, adrenocorticotropic hormone; GnRH, gonadotropin releasing hormone; NTX, N-telopeptides. 
Table 1

Representative studies of bone mineral densityin subjects with depression

\begin{tabular}{|c|c|c|c|}
\hline $\begin{array}{l}\text { Study Design } \\
\text { Setting } \\
\end{array}$ & $\begin{array}{l}\text { Diagnosis, Gender, } \\
\text { Sample Size, }\end{array}$ & $\begin{array}{l}\text { Age (years) } \\
\text { Menopausal State }\end{array}$ & Main Findings \\
\hline $\begin{array}{l}\text { Cross- Sectional Study } \\
\text { at a Psychiatric Clinic } \\
\text { (Petronijevic, } 2008 \\
{[18] \text { ) }}\end{array}$ & $\begin{array}{l}\text { Women with unipolar } \\
\text { depression }(\mathrm{N}=73) \\
\text { Control women } \\
\text { matched by age and } \\
\text { osteoporosis risk factors } \\
(\mathrm{N}=47)\end{array}$ & $\begin{array}{l}\text { Age: 4th decade } \\
\text { (All premenopausal) }\end{array}$ & $\begin{array}{l}\text { Women with depression had: } \\
\Downarrow \text { BMD at the spine and } \\
\text { femoral neck, } \\
\text { Approximately } 45 \% \text { had } \\
\text { osteoporosis } \\
\text { Duration of depression was } \\
\text { inversely related to BMD }\end{array}$ \\
\hline $\begin{array}{l}\text { Cross- Sectional } \\
\text { Evaluation of a } \\
\text { Prospective Cohort: } \\
\text { The POWER Study } \\
\text { (Eskandari, 2007[16]) }\end{array}$ & $\begin{array}{l}\text { Women with current or } \\
\text { past MDD } \\
(\mathrm{N}=89) \\
\text { Control women }(\mathrm{N}=44 \\
\text { matched by age. } \mathrm{BMI}, \\
\text { race }\end{array}$ & $\begin{array}{l}\text { Age: } 3 \text { rd decade } \\
\text { (All premenopausal) }\end{array}$ & $\begin{array}{l}\text { Women with depression had: } \\
\Downarrow \text { BMD at the spine and } \\
\text { femoral neck, } \\
\Uparrow \text { Prevalence of low BMD at } \\
\text { the at the femoral neck and } \\
\text { total hip } \\
\Downarrow \text { Pro-inflammatory and } \Uparrow \\
\text { anti-inflammatory cytokines }\end{array}$ \\
\hline $\begin{array}{l}\text { Cross-Sectional } \\
\text { Evaluation of a } \\
\text { Prospective Cohort } \\
\text { (Niti, 2007 [52]) }\end{array}$ & $\begin{array}{l}\text { Healthy subjects } \\
\text { Community sample } \\
(\mathrm{N}=2,611: \\
\text { Men=963, } \\
\text { Women=1648) } \\
\end{array}$ & $\begin{array}{l}\text { Age: } 5 \text { th decade } \\
\text { (All women } \\
\text { postmenopausal) }\end{array}$ & $\begin{array}{l}\Uparrow \text { Risk of having } \\
\text { osteoporosis if depressed: } \\
\text { (Odds ratio: } 2.32 ; 95 \% \mathrm{CI} \text {; } \\
1.13 \text { to } 4.76 \text { ) }\end{array}$ \\
\hline $\begin{array}{l}\text { Prospective evaluation } \\
\text { of a Mexican American } \\
\text { cohort } \\
\text { (Tolea, } 2007 \text { [9]) }\end{array}$ & $\begin{array}{l}\text { Women with depressive } \\
\text { symptoms } \\
(\mathrm{N}=1,350)\end{array}$ & Age: 7 th decade & $\begin{array}{l}\text { High depressive } \\
\text { symptomatology was } \\
\text { predictive of self-reported } \\
\text { osteoporosis: } \\
\text { Odds ratio: } 1.42,95 \% \mathrm{CI} \\
\text { from } 1.05 \text { to } 1.92 \text {. } \\
\text { Self-reported fractures: } \\
\text { Odds ratio: } 1.43 ; 95 \% \text { CI } \\
1.03,1.99\end{array}$ \\
\hline $\begin{array}{l}\text { Consecutive series of } \\
\text { outpatients at a } \\
\text { psychiatric clinic } \\
(\text { Kahl, 2006 [13]) }\end{array}$ & $\begin{array}{l}\text { Women with borderline } \\
\text { personality disorder } \\
\text { (BPD) } \\
\text { (N=38; } 16 \text { w/o MDD; } \\
22 \text { with MDD) }\end{array}$ & $\begin{array}{l}\text { Age: } 2 \text { nd-3rd decade } \\
\text { (All premenopausal) }\end{array}$ & $\begin{array}{l}\Downarrow \text { BMD (Z scores) in subjects } \\
\text { with BPD+MDD at the } \\
\text { lumbar spine (vs subjects } \\
\text { with BPD only) } \\
\text { and lumbar spine and forearm } \\
\text { vs historical controls } \\
\text { (normative data) }\end{array}$ \\
\hline $\begin{array}{l}\text { Prospective cohort } \\
\text { study: the NHANES I } \\
\text { Study } \\
\text { (Mussolino, 2005[11]) }\end{array}$ & $\begin{array}{l}\text { Healthy subjects } \\
\text { White and black men } \\
\text { and women } \\
(\mathrm{N}=6,195)\end{array}$ & $\begin{array}{l}\text { Age: } 25-74 \text { at } \\
\text { baseline } \\
\text { (Pre and/or } \\
\text { postmenaopausal } \\
\text { women) }\end{array}$ & $\begin{array}{l}\text { Depression was predictive of } \\
\text { hip fracture (Hazard Ratio: } \\
1.9 \text { (CI 1.1.3-3.21; } \mathrm{P}=0.01)\end{array}$ \\
\hline $\begin{array}{l}\text { Cross-sectional } \\
\text { evaluation of a large } \\
\text { cohort } \\
\text { (Wong, 2005 [42]) }\end{array}$ & \begin{tabular}{|l|} 
Healthy subjects \\
Stratified sample of \\
community living \\
Chinese men $(\mathrm{N}=1999)$
\end{tabular} & $\begin{array}{l}\text { Age: } 65 \text { years or } \\
\text { older (average: } 72 \text { ) }\end{array}$ & $\begin{array}{l}\text { Adjusted hip BMD was } 2.1 \% \\
\text { lower in men with depression } \\
\text { (Relative Risk 1.4, CI 1-2.08; } \\
\mathrm{P}=0.05 \text { ) } \\
\text { AP spine was not different } \\
\text { between groups } \\
\text { No differences in fracture } \\
\text { rates between groups } \\
8.5 \% \text { of men met criteria for } \\
\text { clinical depression. }\end{array}$ \\
\hline $\begin{array}{l}\text { Cross-sectional study } \\
\text { of a national } \\
\text { probability sample: } \\
\text { NHANES III Study } \\
\text { (Mussolino,2004 [40]) }\end{array}$ & \begin{tabular}{|l|} 
Healthy subjects \\
Civilian non \\
institutionalized US \\
population from 1988 to \\
1994 non-Hispanic \\
white, non-Hispanic \\
black and Mexican \\
American men \\
$(\mathrm{N}=2,528)$ and women \\
$(\mathrm{N}=2,643)$ \\
\end{tabular} & Age: $20-39$ & $\begin{array}{l}\text { No differences in BMD in } \\
\text { women } \\
\text { Men with MDD had } 5.1 \% \\
\text { lower BMD than men w/o } \\
\text { MDD; } \\
\text { Risk-adjusted odds ratio for } \\
\text { men were: MDD } 1.65, \text { CI } \\
1.08-2.52 ; \mathrm{P}=0.05 ; \\
\text { dysthymia } 1.84 \text {, CI } 1.29-2.62 \\
\mathrm{P}=0.01 \text { ) }\end{array}$ \\
\hline $\begin{array}{l}\text { Prospective cohort } \\
\text { study of risk factors of } \\
\text { osteoporosis } \\
(\text { Whooley, 2004 [41]) }\end{array}$ & $\begin{array}{l}\text { Healthy subjects } \\
(\mathrm{N}=523) \text { evaluated at } \\
\text { baseline and a random } \\
\text { subset evaluated } 3.6 \\
\text { years later }\end{array}$ & Age: 50 or older & $\begin{array}{l}\text { No association between } \\
\text { depressive symptoms and } \\
\text { BMD } \\
\text { No differences in BMD in } \\
\text { subjects with } 6 \text { or more } \\
\text { depressive symptoms vs } \\
\text { subjects with } 5 \text { or fewer } \\
\text { symptoms }\end{array}$ \\
\hline $\begin{array}{l}\text { Prospective population- } \\
\text { based cohort: } \\
\text { the Cardiovascular }\end{array}$ & $\begin{array}{l}\text { Healthy subjects } \\
\text { Caucasian and African } \\
\text { American men and }\end{array}$ & $\begin{array}{l}\text { Age: } 65-100 \\
\text { (All women } \\
\text { postmenopausal) }\end{array}$ & $\begin{array}{l}\text { Depression was negatively } \\
\text { associated with total hip } \\
\text { BMD in the full cohort, and }\end{array}$ \\
\hline
\end{tabular}




\begin{tabular}{|l|l|l|l|}
\hline $\begin{array}{l}\text { Study Design } \\
\text { Setting }\end{array}$ & $\begin{array}{l}\text { Diagnosis, Gender, } \\
\text { Sample Size, }\end{array}$ & $\begin{array}{l}\text { Age (years) } \\
\text { Menopausal State }\end{array}$ & Main Findings \\
\hline Health Study & $\begin{array}{l}\text { Women } \\
\text { (Nobbins, 2001 [46]) }\end{array}$ & & $\begin{array}{l}\text { among Caucasians and } \\
\text { African-American } \\
\text { (Robter statistical adjustment, } \\
\text { depression accounted for 2\% } \\
\text { of the total hip BMD } \\
\text { variability }\end{array}$ \\
\hline
\end{tabular}

